\title{
Cyclopalladated and cycloplatinated benzophenone imines: Antitumor, antibacterial and antioxidant activities, DNA interaction and cathepsin B inhibition
}

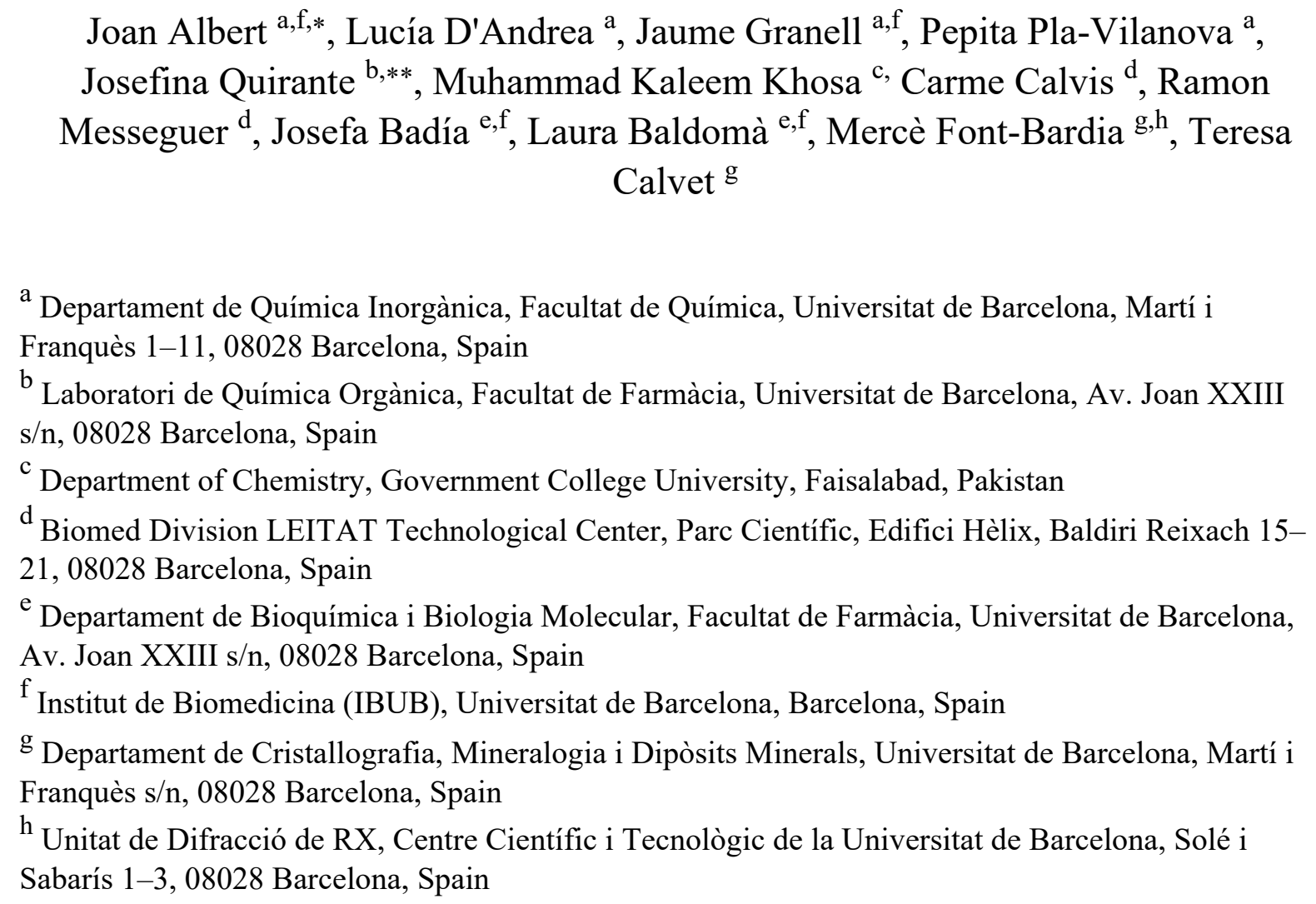

Keywords: Cyclometalated Palladium Platinum Anticancer DNA Metalloproteases 
42

43

44

45

46

47

48

49

50

51

52

53

54

55

56

57

58

59

60

61

\section{ABSTRACT}

The antitumor, antibacterial and antioxidant activity, DNA interaction and cathepsin $\mathrm{B}$ inhibition of cyclo-orthopalladated and -platinated compounds $[\mathrm{Pd}(\mathrm{C}, \mathrm{N})] 2(\mu-\mathrm{X}) 2[\mathrm{X}=\mathrm{OAc}(1), \mathrm{X}=\mathrm{Cl}(2)]$ and trans-N,P-[M(C,N) X(PPh3)] $[\mathrm{M}=\mathrm{Pd}, \mathrm{X}=\mathrm{OAc}(3), \mathrm{M}=\mathrm{Pd}, \mathrm{X}=\mathrm{Cl}(4), \mathrm{M}=\mathrm{Pt}, \mathrm{X}=\mathrm{Cl}$ (5)] are discussed $[(\mathrm{C}, \mathrm{N})=$ cyclo-orthometallated benzophenone imine $]$. The cytotoxicity of compound 5 has been evaluated towards human breast (MDA-MB-231 and MCF-7) and colon (HCT-116) cancer cell lines and that of compounds 1-4 towards the HCT-116 human colon cancer cell line. These cytotoxicities have been compared with those previously reported for compounds 1-4 towards MDAMB-231 and MCF-7 cancer cell lines. Compound 3 and 4 were approximately four timesmore active than cisplatin against theMDA-MB-231 andMCF-7 cancer cell lines, and compound 5, was approximately four times more potent than cisplatin against the HCT-116 cancer cell line. The antibacterial activity of compounds 1-5 was in between the ranges of activity of the commercial antibiotic compounds cefixime and roxithromycin. Complexes 1-2 and 4-5 presented also antioxidant activity. Compounds 1-5 alter the DNA tertiary structure in a similar way to cisplatin, but at higher concentration, and do not present a high efficiency as cathepsin B inhibitors. Compound 5 has not been previously described, and its preparation, characterization, and X-ray crystal structure are reported. 


\section{Introduction}

The application of cyclometalated compounds in medicine and bioimaging is a subject of growing interest [1-3]. In this field, our research group has published some studies on the in vitro antitumor activity of cyclopalladated and cycloplatinated compounds [4-7]. The number of studies related to the anticancer activity of cyclopalladated and cycloplatinated compounds is quite significant $[8,9]$ but very little is known about their other chemotherapeutic activities. Antiparasitic activity has been reported for a fewcyclopalladated and cycloplatinated compounds [5,10-12]. In addition, in a few cases the antibacterial activity of cyclopalladated compounds has also been studied [13-16]. Cycloaurated compounds have also been explored for their antibacterial, antifungal, antiviral and antiparasitic activities $[12,17,18]$.

On the other hand, in recent years, it has become increasingly evident that several cytotoxic metallodrugs exert their biological and pharmacological actions through DNA-independent mechanisms. Accordingly, it is important to explore alternativemechanisms and biological targets for anticancermetallodrugs [19]. Cathepsin B is a cysteine metalloprotease highly upregulated in a wide variety of cancers by mechanisms ranging from gene amplification to post-transcriptional modification. The exact role of cathepsin B in solid tumors has yet to be defined, but it has been proposed to participate inmetastasis, angiogenesis, and tumor progression [20,21]. Recently, compounds based on palladium, platinum, ruthenium, rhenium, gold and tellurium were shown to be effective inhibitors of cathepsin B [12,20-31]. In addition, an excellent correlation between cathepsin B inhibition and cytotoxicity for some dinuclear biphosphane palladacycles [22] and mononuclear platinacycles containing a fluorinated phosphane [28] has been reported. Therefore within this work, we intended to study the capability of the cyclopalladated and cycloplatinated benzophenone imines 1-5 given in Scheme 1 to act as cytotoxic agents, by direct damage on DNA, or/and by inhibiting alternative targets such as cathepsin B, which is overexpressed in many cancer cell lines.

In a precedent paper [32], we reported the antitumor activity of the cyclopalladated benzophenone imines 1-4 depicted in Scheme 1 against the MDA-MB-231 and MCF-7 human breast cancer cell lines and studied their interaction towards DNA by the DNA migration electrophoretic technique. Following this study, here we report: a) the antitumor activity of compounds 1-4 towards the HCT-116 human colon cancer cell line and that of the cycloplatinated compound 5 towards MDA-MB-231 and MCF-7 breast and HCT-116 colon human cancer cell lines, b) the antibacterial activity of compounds $1-5, c)$ the antioxidant activity of compounds $1-5$, expressed as their $\%$ of DPPH free radical scavenging, d) the interaction of compound 5 with DNA by the DNA migration agarose gel electrophoretic assay, and e) the cathepsin B inhibition test for compounds 1-5. 
100

101

102

103

104

105

106

107

108

109

110

111

112

113

114

115

116

117

118

119

120

121

122

123

124

125

126

127

128

129

130

131

132

133

134

135

136

137

138

139

140

141

142

\section{Experimental}

2.1. Chemistry: instruments and reagents

Elemental analyses of C, H and $\mathrm{N}$ were performed with an Eager 1108 microanalyzer. Infrared spectra were recorded on a Nicolet Impact-400 spectrophotometer using pressed disks of dispersed samples of the compounds in KBr. $1 \mathrm{H} \mathrm{NMR} \mathrm{(at} 400 \mathrm{MHz}$ ), $13 \mathrm{C}-\{1 \mathrm{H}\}$ (at $101 \mathrm{MHz}$ ), $195 \mathrm{Pt}-\{1 \mathrm{H}\}$ (at $86 \mathrm{MHz}$ ), and $31 \mathrm{P}-\{1 \mathrm{H}\}$ (at $162 \mathrm{MHz}$ ) NMR spectra were recorded in $\mathrm{CDCl} 3$ at $298 \mathrm{~K}$. Chemical shifts are reported in $\delta$ values (ppm) relative to SiMe4 $(\delta=0.00 \mathrm{ppm})$ for $1 \mathrm{H}$ NMR, to the residual solvent peak for $13 \mathrm{C}-\{1 \mathrm{H}\}(\delta=77.00 \mathrm{ppm})$, to a solution of $\mathrm{K} 2[\mathrm{PtCl} 4]$ in $\mathrm{D} 2 \mathrm{O}(\delta=-1617.00 \mathrm{ppm})$ as an external reference for $195 \mathrm{Pt}-\{1 \mathrm{H}\} \mathrm{NMR}$, and relative to an external solution of trimethylphosphite in deuterated acetone $(\delta=140.18$ ppm relative to $85 \%$ orthophosphoric acid) for $31 \mathrm{P}-\{1 \mathrm{H}\} \mathrm{NMR}$. Coupling constants are given in $\mathrm{Hz}$, and multiplicity (splitting) is expressed as s (singlet), $\mathrm{d}$ (doublet), m (multiplet), and br (broad signal). Low resolution ESI (+) mass spectrawere acquired on an LC/MSD-TOF instrument, utilizing a mixture of $\mathrm{CH} 3 \mathrm{CN}: \mathrm{H} 2 \mathrm{O}(1: 1, \mathrm{v} / \mathrm{v})$ as the eluent. Dry methanol (HPLC grade), dichloromethane, hexanes, ethyl acetate, and diethyl ether were used as received. Sodium acetate was oven-dried at $60^{\circ} \mathrm{C}$, prior to use. The complex cis-[PtCl2(DMSO)2] was prepared following a literature method [33]. Compounds 1-4 were prepared as previously reported [32]. ESI and LC/MSD-TOF refer to Electrospray Ionization and Liquid Chromatography/Mass Selective Detector - Time Of Flight, respectively.

\subsection{Preparation of mixture A}

Cis-[PtCl2(DMSO)2] (301 $\mathrm{mg}, 0.71 \mathrm{mmol})$ and sodium acetate $(61 \mathrm{mg}, 0.74 \mathrm{mmol})$ were brought into a Schlenk flask and evacuated for $10 \mathrm{~min}$, and finally flushed with nitrogen. To this, dry methanol (50 $\mathrm{mL}$ ) was added and the reaction mixture was warmed until complete dissolution of the sample. An excess of benzophenone imine $(150 \mu \mathrm{L}, 162 \mathrm{mg}, 0.89 \mathrm{mmol})$ was next added to the yellow solution, and the resultingmixture was refluxed for 1 day. After this time, dichloromethane (approx. $15 \mathrm{~mL}$ ) was added to the red solution to induce precipitation of the sodium acetate. The suspension was filtered through a pad of celite $(5.0 \mathrm{~cm} \times 2.0 \mathrm{~cm})$ and washed through with further dichloromethane until thewashingswent colorless. Evaporation of the solvent resulted in the formation of a resin, to which hexanes (ca. $15 \mathrm{~mL}$ ) were added. The mixture was energetically stirred for 1-2 days, during which time intense scratching on the vessel surface was required to help promoting precipitation. The beige solid was collected by filtration and air-dried $(305 \mathrm{mg})$. 1H NMR characterization in $\mathrm{CDCl} 3$ revealed that the major components of this solid are trans-N,L-[Pt(C,N)Cl(DMSO)] (A1) and trans-N,L$[\mathrm{Pt}(\mathrm{C}, \mathrm{N}) \mathrm{Cl}(\mathrm{Ph} 2 \mathrm{C}=\mathrm{NH})](\mathrm{A} 2)$ in a 3:1 molar ratio. $1 \mathrm{H} \mathrm{NMR}(400 \mathrm{MHz}, \mathrm{CDCl} 3,298 \mathrm{~K})$ (selected data): A1: 8.83 (br s, $1 \mathrm{H}, \mathrm{NH}), 8.27$ (d, 3JHH = 7.6, 3JPtH = 48.0, 1H, H2), 3.56 (s, 3JPtH = 21.4, 6H, CH3); A2: $10.0($ br s, $1 \mathrm{H}, \mathrm{NH}), 8.92(\mathrm{br} \mathrm{s}, 1 \mathrm{H}, \mathrm{NH}), 8.29(\mathrm{~d}, 3 \mathrm{JHH}=7.2$, partially overlapped with $\mathrm{H} 2$ of $\mathrm{A} 1$, 1H, H2). MSESI (+) (CH3CN:H2O, (1:1)), m/z: A1: 494.1 (calcd. 494.1) [M - Cl + CH3CN]+, 453.1 (calcd. 453.1) [M- Cl]+; A2: 597.2 (calcd. 597.2) [M- Cl+ CH3CN]+, 556.1 (calcd. 556.1) [M- Cl]+. 
The mixture A $(297 \mathrm{mg})$ was dissolved in acetone $(50 \mathrm{~mL})$ giving an orange solution, which was subsequently treated with triphenylphosphane $(160 \mathrm{mg}, 0.61 \mathrm{mmol})$ at room temperature. After $2 \mathrm{~h}$ and $30 \mathrm{~min}$ of stirring, the resulting mixture was concentrated under vacuum. Addition of diethyl ether (approx. $10 \mathrm{~mL}$ ) produced the formation of a yellow precipitate, which was filtered and air-dried (290 $\mathrm{mg}$ ). An additional crop was obtained from the ether mother liquor, which was concentrated to dryness and afterwards vigorously stirred in hexanes (ca. $25 \mathrm{~mL}$ ) for one day. The yellow solid formed was filtered off and dried in air (40 mg). Both crops were combined, dissolved in ethyl acetate, and subjected to column chromatography $(\mathrm{SiO} 2,3.0 \mathrm{~cm} \times 30 \mathrm{~cm}$ ) using a 100:60 hexanes:ethyl acetate mixture as eluent. The eluted band led to the required product after solvent removal and addition of hexanes (ca. $10 \mathrm{~mL})$. The yellow solid obtained was recovered by filtration and air-dried $(128 \mathrm{mg}, 27 \%$ yield, relative to the starting cis-[PtCl2(DMSO)2]). Yellow crystals of 5 suitable for X-ray analysis were grown at room temperature from a dichloromethane solution layered by hexanes in a 1:1 volume ratio. IR (selected data), $v(\mathrm{~cm}-1)$ : $3315(\mathrm{NH} \mathrm{st}), 1583(\mathrm{C}=\mathrm{N} \mathrm{st}), 1096$ (q, X-sensitive PPh3). 1H NMR (400 MHz, CDCl3, 298 K): 9.34 (br s, 1 H, NH), 7.80-7.75 (m, 6 H, o-PPh3), 7.61-7.52 (m, 5 H, H8 + H9 + H10), 7.47-7.37 (m, 9 H, p-PPh3 + m-PPh3), 7.16 (d, 1 H, 3JHH = 7.8, H5), 6.92-6.88 (m, 1 H, H4), 6.74-6.58 (m, $2 \mathrm{H}, \mathrm{H} 2+\mathrm{H} 3) .13 \mathrm{C}-\{1 \mathrm{H}\} \mathrm{NMR}(101 \mathrm{MHz}, \mathrm{CDCl} 3,298 \mathrm{~K}): 189.1$ (d, 3JCP = 2.6, C7 = $\mathrm{NH}), 145.9(\mathrm{~d}, 3 \mathrm{JCP}=1.5, \mathrm{C6}), 145.3(\mathrm{~d}, 2 \mathrm{JCP}=6.7, \mathrm{C} 1), 137.8(\mathrm{~d}, 3 \mathrm{JCP}=5.9, \mathrm{C} 2), 135.4(\mathrm{~d}, 2 \mathrm{JCP}=$ 11.3, o-CPPh3), 134.9 (d, 4JCP = 5.0, C8), $132.7(\mathrm{~d}, 4 \mathrm{JCP}=2.0, \mathrm{C} 3), 131.3$ (s, C5), 131.2 (s, C11), $130.8(\mathrm{~d}, 4 \mathrm{JCP}=2.5$, p-CPPh3), $130.1(\mathrm{~d}, 1 \mathrm{JCP}=60.2$, i-CPPh3), $129.0(\mathrm{~s}, \mathrm{C} 10), 128.0(\mathrm{~d}, 3 \mathrm{JCP}=11.0$, m-CPPh3), 127.8 (s, C9), 122.6 (s, C4). 31P-\{1H\} NMR (162 MHz, CDCl3, $298 \mathrm{~K}): 22.64$ (s, 1JPtP = 4068). 195Pt- $\{1 \mathrm{H}\}$ NMR (86 MHz, $\mathrm{CDCl} 3,298 \mathrm{~K}):-4206.6(\mathrm{~d}, 1 \mathrm{JPtP}=4109)$. MS-ESI $(+)$ (CH3CN:H2O, (1:1)), m/z: 1309.2 (calcd. 1309.2) [2M - Cl]+, 678.2 (calcd. 678.2) $[\mathrm{M}-\mathrm{Cl}+$ $\mathrm{CH} 3 \mathrm{CN}]+, 637.1$ (calcd. 637.1) [M-Cl]+. Anal. Calcd. for C31H25ClNPPt: C 55.32\%, H 3.74\%, N $2.08 \%$. Found: C 55.16\%, H 3.81\%, N 1.97\%.

\subsection{X-ray crystal structure determination of compound 5}

A yellow prism-like specimen of compound $5(\mathrm{C} 31 \mathrm{H} 25 \mathrm{ClNPPt})$, approximate dimensions $0.208 \mathrm{~mm} \times$ $0.249 \mathrm{~mm} \times 0.554 \mathrm{~mm}$, was used for the X-ray crystallographic analysis. The X-ray intensity data were measured on a D8 Venture system equipped with a multilayer monochromator and a Mo microfocus $(\lambda$ $=0.71073 \AA$ ). A total of 2848 frames were collected. The total exposure time was $7.91 \mathrm{~h}$. The frames were integrated with the Bruker SAINT software package [34] using a narrow-frame algorithm. The integration of the data using a triclinic unit cell yielded a total of 91349 reflections to a maximum $\theta$ angle of $36.42^{\circ}(0.60 \AA$ resolution), of which 24376 were independent (average redundancy 3.747 , completeness $=99.7 \%$, Rint $=4.35 \%)$ and $23182(95.10 \%)$ were greater than $2 \sigma(\mathrm{F} 2)$. The final cell constants of $\mathrm{a}=9.709(1) \AA, \mathrm{b}=10.255(1) \AA, \mathrm{c}=14.027(2) \AA, \alpha=74.231(3)^{\circ}, \beta=72.613(4)^{\circ}, \gamma=$ $77.491(4)^{\circ}$, volume $=1268.6(3) \AA 3$, are based upon the refinement of the XYZ-centroids of 195 reflections above $20 \sigma(\mathrm{I})$ with $5.583^{\circ} \mathrm{b} 2 \theta \mathrm{b} \mathrm{58.11^{ \circ }}$. Data were corrected for absorption effects using the multi-scan method (SADABS). The ratio of minimum to maximum apparent transmission was 0.727 . The structure was solved and refined using the Bruker SHELXTL Software Package [35], with $Z=2$ for the formula unit, C31H25CINPPt. The final anisotropic full-matrix least-squares refinement on F2 with 316 variables converged at $\mathrm{R} 1=1.67 \%$, for the observed data and $\mathrm{wR} 2=4.29 \%$ for all data. The goodness-of-fit was 1.116. The largest peak in the final difference electron density synthesis was 1.100 $\mathrm{e}-/ \AA 3$ and the largest hole was $-1.695 \mathrm{e}-/ \AA 3$ with an RMS (Root Mean Square) deviation of 0.122 $\mathrm{e}-/ \AA 3$. On the basis of the final model, the calculated density was $1.762 \mathrm{~g} / \mathrm{cm} 3$ and $\mathrm{F}(000), 656 \mathrm{e}-$. 


\subsection{Cell culture}

Breast cancer [MCF-7 (Michigan Cancer Foundation-7) and MBAMD-231(M. D. Anderson-Metastasic Breast-231)] and colon cancer [HCT-116 (Human Colon Tumor-116)] cellswere grown as a monolayer culture in minimum essential medium (DMEM with L-glutamine, without glucose and without sodium pyruvate) in the presence of $10 \%$ heat-inactivated fetal calf serum, $10 \mathrm{mM}$ D-glucose and $0.1 \%$ streptomycin/penicillin, in standard culture conditions (humidified air with $5 \% \mathrm{CO} 2$ at $37{ }^{\circ} \mathrm{C}$ ).

\subsection{Cell viability assay}

A stock solution $(50 \mathrm{mM})$ of each compound was prepared in high purity DMSO. Then, serial dilutions were made with DMSO (1:1) and finally a 1:500 dilution of the diluted solutions of compounds on cell media was prepared. In this way DMSO concentration in cell media was always the same. The assay was performed as described by Givens et al. [36]. HCT-116, MDA-MB-231 and MCF-7 cells were plated at 5000 cells/well, respectively, in $100 \mathrm{~mL}$ media in tissue culture 96-well plates (Cultek). After $24 \mathrm{~h}$, media was replaced by $100 \mathrm{~mL} /$ well of drug serial dilutions. Control wells did not contain compounds 1-5. Each point concentration was run in triplicate. Reagent blanks, containing media and colorimetric reagent without cells were run on each plate. Blank values were subtracted from test values and were routinely $5-10 \%$ of the control values. Plates were incubated $72 \mathrm{~h}$. Hexosaminidase activity was measured according to the following protocol. The media were removed and cells were washed once with PBS (Phosphate Buffered Saline). Then, $60 \mathrm{~mL}$ of substrate solution (pnitrophenol-N-acetyl$\beta$-D-glucosamide $7.5 \mathrm{mM}$, sodium citrate $0.1 \mathrm{M}$ at pH5.0, and $0.25 \%$ Triton $\mathrm{X}-100$ ) was added to each well and incubated at $37^{\circ} \mathrm{C}$ for $1-2 \mathrm{~h}$. After this incubation time, a bright yellow appeared. Then, the plates were developed by adding $90 \mathrm{~mL}$ of developer solution (glycine $50 \mathrm{mM}, \mathrm{pH} 10.4$; EDTA $5 \mathrm{mM}$ ) and the absorbance was recorded at $410 \mathrm{~nm}$.

\subsection{Antibacterial activity}

Test compounds (1-5) were screened to determine their antibacterial activity against six bacterial strains; three gram positive Staphylococcus aureus (ATCC 6538), Micrococcus luteus (ATCC 10240) and Bacillus subtilis (ATCC 6633) and three gram negative Escherichia coli (ATCC 15224), Enterobacter aerogenes (ATCC 13048) and Bordetella bronchiseptica (ATCC 4617) by using "Disc diffusion method" [37-39]. The organisms were cultured in nutrient broth at $37^{\circ} \mathrm{C}$ for $24 \mathrm{~h}$. One percent broth culture containing approx. 106 colony-forming units $(\mathrm{CFU} / \mathrm{mL})$ of test strain were added to nutrient agar medium at $45^{\circ} \mathrm{C}$ and poured into sterile petri plates. The mediumwas allowed to solidify. Five microliters of the test compound ( $40 \mathrm{mg} / \mathrm{mL}$ in DMSO) was poured on 4-mm sterile paper disks and placed on nutrient agar plates respectively. In each plate DMSO served as negative control and standard antibacterial drugs roxithromycin $(1 \mathrm{mg} / \mathrm{mL})$ and cefixime $(1 \mathrm{mg} / \mathrm{mL})$ served as a positive control. Triplicate plates of each bacterial strainwere prepared. The plates were incubated at $37^{\circ} \mathrm{C}$ for $24 \mathrm{~h}$. The antibacterial activity was determined by measuring the diameter of zones showing complete inhibition (mm). 
The scavenging activity of DPPH free radicals of compounds $1-5$ was determined according to the method reported earlier with minor modifications [40,41]. A stock solution $(5 \mathrm{mg} / \mathrm{mL})$ of test solution was prepared in DMSO. Serial dilutions were carried out to obtain concentrations of 5, 10, 20, 40, 100, $200 \mu \mathrm{g} / \mathrm{mL} .15 \mu \mathrm{L}$ of each test sample or DMSO in case of negative control was mixed with $2985 \mu \mathrm{L}$ of $0.1 \mathrm{mM}$ methanolic solution of DPPH in glass vials so that the final volume was $3 \mathrm{~mL}$. The vials were capped and reaction mixture was incubated for $30 \mathrm{~min}$ at $37^{\circ} \mathrm{C}$ in dark. After incubation the change in colour (from deep-violet to light-yellow) of DPPH solution was measured by taking absorbance of reaction mixtures at $517 \mathrm{~nm}$ on a PDA (photo diode array) spectrophotometer (Agilent 8453). Mixture of $2985 \mu \mathrm{L}$ of methanol and $15 \mu \mathrm{L}$ of DMSOwas used as a blank for spectrophotometric measurements. Each concentration was assayed in triplicate. Ascorbic acid was used as a reference standard and dissolve in distilled water to make the stock solution with the same concentration $(5 \mathrm{mg} / \mathrm{mL})$. Control was prepared containing the same volume without any test solution and reference ascorbic acid. The \% scavenging of the DPPH free radical was calculated by using the following formula.

$\%$ scavenging activity $=\frac{\text { absorbance of control-absorbance of test sample }}{\text { absorbance of control }} \times 100$

\subsection{DNA migration studies}

A stock solution $(10 \mathrm{mM})$ of each compound was prepared in high purity DMSO. Then, serial dilutions were made in MilliQ water (1:1). Plasmid pBluescript SK + (Stratagene) was obtained using QIAGEN plasmid midi kit as described by the manufacturer. Interaction of drugs with pBluescript SK + plasmid DNA was analyzed by agarose gel electrophoresis following a modification of the method described by Abdullah et al. [42]. Plasmid DNA aliquots $(40 \mu \mathrm{g} / \mathrm{mL})$ were incubated in TE buffer $(10 \mathrm{mM}$ Tris-HCl, $1 \mathrm{mM}$ EDTA, pH 7.5) with different concentrations of compounds $1-5$ ranging from $0 \mu \mathrm{M}$ to $200 \mu \mathrm{M}$ at $37^{\circ} \mathrm{C}$ for $24 \mathrm{~h}$. Final DMSO concentration in the reactions was always lower than $1 \%$. For comparison, cisplatin and ethidium bromide were used as reference controls. Aliquots of $20 \mu \mathrm{L}$ of the incubated solutions of compounds containing $0.8 \mu \mathrm{g}$ of DNA were subjected to $1 \%$ agarose gel electrophoresis in TAE buffer (40 mM Tris-acetate, 2 mM EDTA, $\mathrm{pH}$ 8.0). The gelwas stained in TAE buffer containing ethidiumbromide $(0.5 \mathrm{mg} / \mathrm{mL})$ and visualized and photographed under UV light.

\subsection{Cathepsin B inhibition assay}

Aldrich (C6286). The colorimetric cathepsin B assay was performed as described by Casini et al. [27], with fewmodifications. Briefly, the reaction mixture contained $100 \mathrm{mM}$ sodium phosphate ( $\mathrm{pH}$ 6.0), 1 mM EDTA and $200 \mu \mathrm{M}$ sodium N-carbobenzoxy-L-lysine p-nitrophenyl ester as substrate. To have the enzyme catalytically active before each experiment the active site of the cysteine was reduced by treatment with dithiothreitol (DTT). For this purpose, $5 \mathrm{mM}$ DTT was added to cathepsin B sample, before dilution, and incubated $1 \mathrm{~h}$ at $30^{\circ} \mathrm{C}$. To test the inhibitory effect of the compounds $1-5$ on cathepsin $\mathrm{B}$, activity measurements were performed in triplicate using fixed concentrations of enzyme $(500 \mathrm{nM})$ and substrate $(200 \mu \mathrm{M})$. Compounds were used at concentrations ranging from 10 to $100 \mu \mathrm{M}$. Previous to the addition of substrate, cathepsin B was incubated with the different compounds at $25^{\circ} \mathrm{C}$ 
276 for $24 \mathrm{~h}$. The cysteine proteinase inhibitor E-64 was used as a positive control of cathepsin B inhibition. 277 Complete inhibition was achieved at $10 \mu \mathrm{M}$ concentration of E-64. Activity was measured over $1.5 \mathrm{~min}$. 278 at $326 \mathrm{~nm}$ on a UV-1603 spectrophotometer (Shimadzu).

279

280 


\section{Results and discussion}

\subsection{Synthesis of compounds $1-5$}

Scheme 1 shows the methods of preparation of compounds $1-5$ and the numbering of the hydrogen and carbon atoms of the benzophenone imine for the discussion that follows.

Cyclopalladated benzophenone imines 1-4 were prepared according to themethods recently reported by our research group [32]. Mixture A was prepared by a modification of the reported procedure for the cycloplatination of benzophenone imine [43,44]. Cis-[PtCl2(DMSO)2] and NaOAc inmolar ratio 1:1 were treated with an excess of benzophenone imine in dry methanol under nitrogen and at reflux for 24 $\mathrm{h}$. In these conditions, we were able to isolate mixture $\mathrm{A}$ in a moderate amount, which contained as major components the cycloplatinated compounds $[\mathrm{Pt}(\mathrm{C}, \mathrm{N}) \mathrm{Cl}(\mathrm{L})] \mathrm{A} 1(\mathrm{~L}=\mathrm{DMSO})$ and $\mathrm{A} 2(\mathrm{~L}=$ benzophenone imine). Other minor compounds present in mixture A could not be characterized. Mixture A was studied by $1 \mathrm{H}$ NMR and ESI mass spectrometry. Analysis of the integrals of the $1 \mathrm{H} \mathrm{NMR}$ indicates that compounds $\mathrm{A} 1$ and $\mathrm{A} 2$ were the major components of mixture $\mathrm{A}$ and that the molar ratio between them was $\mathrm{A} 1 / \mathrm{A} 2 \approx 3 / 1$. Compound 5 of formula trans- $\mathrm{N}, \mathrm{P}-[\mathrm{Pt}(\mathrm{C}, \mathrm{N}) \mathrm{Cl}(\mathrm{PPh} 3)]$ was prepared by reaction between mixture $\mathrm{A}$ and $\mathrm{PPh} 3$ via a substitution reaction of the $\mathrm{L}$ ligand in compounds $\mathrm{A} 1$ and A2 for the PPh3 ligand. Compound 5 was obtained in $27 \%$ yield relative to the initial cis[PtCl2(DMSO)2] and was fully characterized by elemental analysis, IR, NMR and mass spectrometry. In addition, its crystal structure was determined by X-ray diffraction.

In the IR spectrum, compound 5 presented the $\mathrm{N} \backslash \mathrm{H}$ and $\mathrm{C} \_\mathrm{N}$ stretchings and the $\mathrm{q} X$ sensitive band of the coordinated $\mathrm{PPh} 3$ molecule at 3315, 1583 and $1096 \mathrm{~cm}-1$, respectively [32]. In the ESI mass spectrometry, compound 5 produced intense signals for the cations $[\mathrm{M}-\mathrm{Cl}+\mathrm{CH} 3 \mathrm{CN}]+$ and $[\mathrm{M}-\mathrm{Cl}]+$, in accordance with the labile nature of $\mathrm{Pt}(\mathrm{II}) \backslash \mathrm{Cl} \sigma$ bond and the coordinative nature of themolecules of acetonitrile, which was used as a solvent in this technique [45]. The most interesting features of the $1 \mathrm{H}$ NMR spectrum of compound 5 were: i) the lack of the signal due to theH1 proton,which demonstrated its ortho-metallated nature, ii) the chemical shift of its $\mathrm{NH}$ proton $(9.34 \mathrm{ppm})$ relative to free benzophenone imine ( $8.40 \mathrm{ppm})$, which was consistent with the coordination of the iminic nitrogen to the platinum(II) center, and iii) the chemical shift of the H2-H5 protons of the ortho-platinated phenyl ring in the interval between 7.16 and $6.58 \mathrm{ppm}$, which was consistent with the trans-N,P configuration of compound $5[32,45-48]$. Protons H2-H5 present these low chemical shifts because they are located in the shielding zone of the $\mathrm{PPh} 3$ aromatic rings of compound 5 [32,35-38]. The $\mathrm{kCl}, \mathrm{kN}$ chelate coordinationmode of the benzophenone imine in compound 5 could also be determined by $13 \mathrm{C}-\{1 \mathrm{H}\}$ NMR since, in this experiment, the $13 \mathrm{C}(\mathrm{C} 1$ and $\mathrm{C} 7)$ atoms produced doublets due to the coupling of these $13 \mathrm{C}$ nuclei with the $31 \mathrm{P}$ nucleus [45].

$31 \mathrm{P}-\{1 \mathrm{H}\}$ NMR of compound 5 produced a singlet at 22.64 ppmwith the expected satellites for 195Pt with a coupling constant between 31P and $195 \mathrm{Pt}$ of $4068 \mathrm{~Hz}$, and the $195 \mathrm{Pt}-\{1 \mathrm{H}\}$ NMR produced a doublet at $-4206.6 \mathrm{ppm}$ with a coupling constant between 31P and 195Pt of $4068 \mathrm{~Hz}$. These chemical shifts for $31 \mathrm{P}$ and $195 \mathrm{Pt}$ and coupling constant between $31 \mathrm{P}$ and $195 \mathrm{Pt}$ were quite similar to those previously reported for compounds of formula trans-N,P-[Pt $(\mathrm{C}, \mathrm{N}) \mathrm{Cl}(\mathrm{PPh} 3)]$, being $(\mathrm{C}, \mathrm{N})$ an orthocycloplatinated benzalimine or cycloplatinated ferrocenylimine with the iminic bond included in the metalacycle $[49,50]$. 
Suitable crystals for the X-raymolecular crystal structure determination of compound 5 were grown by slow evaporation of a solution of compound 5 in $\mathrm{CH} 2 \mathrm{Cl} 2 /$ hexane in a volume ratio 1:1. Compound 5 crystallized in the triclinic space group $\mathrm{P}-1$ with $\mathrm{Z}=2$. Fig. 1 shows the $\mathrm{X}$-ray molecular structure of 5 and gives selected distances and bond angles. The molecular structure determined by X-ray diffraction confirms the proposed structure for compound 5. The benzophenone imine is coordinated in a chelate form to the platinum(II) through the $\mathrm{N} 1$ and $\mathrm{C} 13$ atoms, and a chlorido ligand and the phosphorus atom of the triphenylphosphane ligand complete the square-planar coordination sphere of the platinum(II) center. The triphenylphosphane ligand is in trans position to the iminic nitrogen atom, in accordance with the trans-N,P configuration proposed for compound 5 by NMR. Distances and angles around the platinum(II) center are between the normal intervals [50], being the $\mathrm{C}(13)-\mathrm{Pt}(1)-\mathrm{N}(1)\left[79.80(5)^{\circ}\right]$ and $\mathrm{C}(13)-\mathrm{Pt}(1)-\mathrm{Cl}(1)\left[167.74(4)^{\circ}\right]$ those that deviated most fromthe ideal angles for a square planargeometry $\left(90\right.$ and $\left.180^{\circ}\right)$. The atoms coordinated to the platinum(II) center (C11, P1, C13 and N1) were almost in a plane and the metalacycle (Pt1, C13, C8, C1 and N1) was practically planar. The $\mathrm{N} 1$ atom $(-0.068 \AA)$ for the coordination plane and the $\mathrm{C} 1(-0.045 \AA)$ atom for the metalacycle were those that were deviated most from their respective planes. The coordination plane (C11, P1, C13 and N1) and the ortho-metalated phenyl ring $(\mathrm{C} 13, \mathrm{C} 12, \mathrm{C} 11, \mathrm{C} 10, \mathrm{C} 9$ and $\mathrm{C} 8)$ were almost coplanar, being the angle between these two planes $4.84^{\circ}$, and the angle between the planes of the non-metalated phenyl ring $(\mathrm{C} 7$, $\mathrm{C} 6, \mathrm{C} 5, \mathrm{C} 4, \mathrm{C} 3$ and $\mathrm{C} 2$ ) and the metalacycle was $45.81^{\circ}$.

\subsection{Stability and behavior in solution of compounds $1-5$}

Compounds 1-5 were stable for long periods of time in contact with air, both in the solid state and in $\mathrm{CDCl} 3$ solution. These compoundswere also soluble in DMSO. In this solvent, the dinuclear compounds 1 and 2 should be converted by a splitting reaction into the mononuclear compounds I of formula trans$\mathrm{N}, \mathrm{S}-[\mathrm{Pd}(\mathrm{C}, \mathrm{N})(\mathrm{S}-\mathrm{DMSO}) \mathrm{X}](\mathrm{X}=\mathrm{OAc}$ or $\mathrm{Cl})[45,51]$. In DMSO as solvent, the exchange of $\mathrm{PPh} 3$ for DMSO in compounds $3-5$ does not seemlikely because the favorable thermodynamic reaction is the inverse of this reaction [52]. In addition, in the biological media, complexes I, 3, 4 and 5 could be converted into the ionic aqua complexes $[\mathrm{Pd}(\mathrm{C}, \mathrm{N})(\mathrm{H} 2 \mathrm{O}) 2] \mathrm{X}(\mathrm{X}=\mathrm{OAc}, \mathrm{Cl})$ (compounds II) and trans$\mathrm{N}, \mathrm{P}-[\mathrm{M}(\mathrm{C}, \mathrm{N})(\mathrm{PPh} 3)(\mathrm{H} 2 \mathrm{O})] \mathrm{X}(\mathrm{M}=\mathrm{Pd}, \mathrm{X}=\mathrm{OAc}$ or $\mathrm{Cl}$ and $\mathrm{M}=\mathrm{Pt}, \mathrm{X}=\mathrm{Cl}$ ) (compounds III) by substitution of the chlorido and DMSO ligands of compounds I and the chlorido ligands of compounds 3-5 for water molecules, respectively. Therefore, we propose that the species responsible for the biological activities studied below are the ionic aqua complexes II and III commented above [32].

\subsection{Antiproliferative studies}

Compound 5was evaluated in vitro for inhibition of cell proliferation against MDA-MB-231 and MCF7 human breast cancer cell lines, using cisplatin as a positive control. All the investigated compounds (1-5) were also evaluated against the cisplatin resistant HCT-116 human colon cancer cell line using cisplatin as a reference. The effects of the assayed palladacycles (1-4) and platinacycle (5) on the growth of the selected cell lines were assessed after $72 \mathrm{~h}$ and the IC50 values of compounds $1-5$ resulting from 
an average of two experiments are listed in Table 1 . The cytotoxicity of compounds $1-4$ towards the human breast MDA-MB-231 andMCF-7 cancer cell lines has been previously reported and their IC50 values are included in Table 1 for a comparative purpose [32].

The in vitro data for the antiproliferative effect of 1-5 (Table 1) reveals that the different complexes inhibit cell proliferation in varying degrees depending on the cell line assayed. Most of the compounds exhibited a remarkable antiproliferative activity with IC50 values lower than those of cisplatin in the three cell lines assayed. Platinacycle 5 showed the highest cytotoxicity towards the HCT-116 cancer cells, while palladacycles 3 and 4 were the most potent against the MDAMB-231 and MCF-7 cancer cells. Interestingly, platinacycle 5 was found to inhibit cell growth proliferation of the HCT-116 colon cell line at a concentration approximately four times lower than cisplatin. In addition, we reported recently [32] that compounds 3 and 4 were approximately four times more potent than cisplatin against the MDA-MB231 and MCF-7 human breast cancer cell lines. It should also be noted that free benzophenone iminewas not active against the studied tumor cell lines.

\subsection{Antibacterial activity}

Resistance to chemotherapeutic agents is a common drawback of both anticancer and anti-infectious treatments. Hence, there is a need for new class of chemotherapeutic drugs in treating cancer cells and pathogenic microorganisms. On the other hand, patientswith neoplastic disorderswho are subjected to chemotherapeutic treatment are susceptible to microbial infections due to the subsequent drop of immunity. Therefore, the search of single drugs, whichwould possess dual anticancer and antibacterial activity, might be advantageous both therapeutically and cost-effectively.

Based on the previous assumptions, compounds $1-5$ were screened for their antibacterial activity against three Gram-positive (S. aureus, M. luteus and B. subtilis) and three Gram-negative (E. coli, E. aerogenes and B. bronchi) bacterial strains by the disk diffusion method. The commercial antibiotics cefixime (third generation cephalosporin) and roxithromycin (semi-synthetic macrolide) were used as positive controls. The results of antibacterial activities in the form of MIC are summarized in Table 2.

Compounds 1-5 showed varying degrees of antibacterial activity with MIC values in the interval 0.18 $0.34 \mu \mathrm{M}$ against the studied Gram-positive and Gram-negative bacterial strains (see Table 2). The antibacterial activity of compounds $1-5$ is in between the ranges of activity of the commercial antibiotic cefixime and roxithromycin. It is interesting to note that all of the compounds showed antibacterial activity against the Gram-negative E. aerogenes strain and that compounds 1-5 were more active against Gram-negative strains than Grampositive strains. This latter result is interesting since Gram-negative bacterial resistance is a burgeoning problem in intensive care units [53]. The best antibacterial activity was provided by platinacycle 5, which exhibit MIC values lower than that of roxithromycin against $\mathrm{E}$. coli (Gram-negative), E. aerogenes (Gram-negative) and B. subtilis (Gram-positive).

\subsection{Antioxidant activity}

The potential preventive anticancer effects of antioxidants, found in high concentrations in many phytochemicals, have become a major focus of research in recent years. These agents block free radical formation as an important mediator of their anticancer effects. Despite accumulating evidence to suggest an important role of antioxidants in cancer prevention, there has been much controversy over their potential therapeutic applications [54-58]. Very recently, antioxidant phytochemicals have found a 
414 chemopreventive effect in platins based chemotherapies [59-61]. Furthermore, the biological activity 415 of specific platinum derivatives, such as the platinum nitrosyl complexes are presumable due in part to 416 the antioxidant properties of the nitrosyl pharmacophore [62]. Therefore we were interested in 417 evaluating the antioxidant capability of the studied cyclometalated complexes.

418 The antioxidant activity of compounds 1-5 was evaluated by their DPPH (1,1-diphenyl-2419 picrylhydrazyl) free radical scavenging activity. The DPPH monoradical presents a strong absorption at $420517 \mathrm{~nm}$, which gives place to its violet colour. DPPH colour changes to light yellow when it accepts an 421 electron or a hydrogen atom from an antioxidant compound. This discoloration can be quantitatively measured from the change in absorbance. Free radical scavenging activity of antioxidant compounds is concentration-dependent. Then, the radical scavenging activity increases as concentration of the antioxidant compound increases, and a low IC50 value reflects a high antioxidant activity $[40,41]$.

DPPH free radical scavenging activities of complexes $1-5$ were assayed at six concentrations $(200,100$, $40,20,10$ and $5 \mu \mathrm{g} / \mathrm{mL}$ ) and the results are summarized in Table 3 . Ascorbic acid was used as a positive control. As expected, DPPH free radical scavenging activity of tested compounds was concentration dependent. Hence higher radical scavenging was observed at higher concentrations, i.e. $200 \mu \mathrm{g} / \mathrm{mL}$. DPPH scavenging analysis showed that compounds $1-2$ and 4-5 are good scavengers of DPPH by scavenging $69-81 \%$ of the radicals at $200 \mu \mathrm{g} / \mathrm{mL}$. This scavenging activity is very close to that of ascorbic acid $(87 \%)$ at the same final concentration $(200 \mu \mathrm{g} / \mathrm{mL})$. IC50 values for complexes $1-2$ and 4-5 for the DPPH free radical scavenging were in the interval between 0.12 and $0.14 \mu \mathrm{M}$. It should be noted that the mononuclear palladium(II) compound 3, with the terminal acetate ligand did not present any significant antioxidant activity. At present, we cannot give a mechanism for the DPPH scavenging activity of these kinds of compounds.

\subsection{DNA migration studies}

The interaction of compound 5 withDNA was studied by its ability to modify the electrophoretic mobility of the supercoiled closed circular (ccc) and the open circular (oc) forms of pBluescript SK + plasmid DNA (Fig. 2). The ccc formusuallymoves faster due to its compact structure. For comparison purposes cisplatin and ethidium bromide were included in the experiment. When the test compounds were incubated with plasmid DNA at $37{ }^{\circ} \mathrm{C}$, they coordinated to DNA molecule, which in some extentwas cleaved into fragments, and the brightness of the band diminished in gel.

447 In spite of the high antiproliferative activity of compound 5, it was less efficient than cisplatin for removing the supercoils frompBluescript SK+ plasmid DNA, suggesting that the unwinding of the DNA is not the key factor responsible of their cytotoxicity (Fig. 2) [32].

450 An unwinding experiment was performed with increasing concentration of compound 5 ranging from 0 to $200 \mu \mathrm{M}$ and $40 \mu \mathrm{g} / \mathrm{mL}$ of pBluescript (Fig. 2). In the presence of platinacycle 5, the rate of migration of the supercoiled band (ccc) decreased and tended to approach that of the nicked relaxed band (oc) at concentration $25 \mu \mathrm{M}$. At higher concentration, an unwinding of negative to positive supercoiled DNA was displayed in the electrophoretogram (Fig. 3, compound 5, lanes 6-8). The same effect was observed for cisplatin (Fig. 2, cisplatin, lanes 3 and 5).

456 Compounds 1-4 were less efficient than compound 5 in removing the supercoils of DNA [32]. Up to 50 $457 \mu \mathrm{M}$, only a slight decrease in the rate of migration of the supercoiled closed circular form was observed 
458 for the dinuclear compound 2. At $100 \mu \mathrm{M}$, palladium compounds $1-4$ greatly altered the mobility of the 459 plasmid DNA. The unwinding of negative to positive supercoiled DNA was also observed for the Pd(II) 460 complexes $1-4$ but at $200 \mu \mathrm{M}$.

461 Thus, on the basis of the alteration of the electrophoretic mobility of pBluescript plasmid DNA, it is 462 hypothesized that compounds 1-5 alter the DNA tertiary structure by the same mechanism than 463 cisplatin, but at higher concentrations.

\subsection{Cathepsin B inhibition}

The cytotoxicity of some dinuclear biphosphane palladacycles (Fig. 3, compounds X) [22] and mononuclear platinacycles with a fluorinated phosphane ligand (Fig. 3, compounds Y) [28] has been related to their cathepsin B inhibitory properties. In addition, several mononuclear cyclopalladated and cycloaurated complexes (Fig. 3, compounds Z) with antiparasitic activity were also excellent inhibitors of cathepsin B [12]. Considering the interaction of cyclopalladated compounds with cathepsin B, it is worthy of mention that their inhibition properties are very dependent on their structure and their IC50 values vary in a very wide range [22].

474 Based on the precedent results, we were interested in testing the efficiency of compounds 1-5 as inhibitors of cathepsin B. Fig. 4 shows that compounds 1-5 inhibit cathepsin B in a dose dependent manner but none of compounds 1-5 had a high efficiency as cathepsin B inhibitor. Among them, only compound 4 inhibited more than $50 \%$ the enzyme activity at $100 \mu \mathrm{M}$ concentration. Platinacycle 5 presented a cathepsin B inhibition efficiency lower than that of palladacycles $1-4$. This result should be relatedwith the great reactivity of the palladium(II) centers in compounds $1-4$ in relation to the platinum(II) center in compound 5 [8].

481 The low activity of compounds 1-5 for the inhibition of cathepsin B could be relatedwith an insufficient targeting of compounds 1-5 for the active site of cathepsin B orwith a lack of reactivity of their metal center for the active site of cathepsin B [63]. It should be noted that a hydrogen bond between the N-H function of compounds $1-5$ and the anionic $\mathrm{X}$ ligand trans to the metalated carbon atom could render 


\section{Conclusions}

The chemotherapeutic properties of cyclopalladated and cycloplatinated benzophenone imines studied in this work and in a previous one [32] show that these kinds of compounds have potential as anticancer agents, and they also present antibacterial and antioxidant activity. The best results for the three activities reported here (cytotoxicity versus HC-T116 colon cancer cells, antibacterial activity againstGramnegative microorganisms and antioxidant properties) were found for the newly prepared and characterized cycloplatinated complex 5.

Cyclopalladated compounds 3-4 showed a remarkable antiproliferative activity against MDA-MB-231 and MCF-7 breast human cancer cell lines and produced an approximately four-fold increase in potency with regard to cisplatin [32]. In addition, platinacycle 5 also showed an approximately four-fold increase in potency in relation to cisplatin in human HCT-116 colon cancer cells [this work]. These results uncover a greater selectivity of platinacycle 5 against the HCT-116 colon cancer cell line, whereas palladacycles 3 and 4 exhibit a greater selectivity for MDA-MB231 and MCF-7 breast cancer cells.

Interestingly, compounds 1-5 also presented antibacterial and antioxidant activity. Compounds 1-5 exhibited greater activity against Gram-negative than against Gram-positive bacterial strains, with MIC values between those of the commercial antibiotic cefixime and roxithromycin. The platinumcompound 5 turned out to bemore potent in antibacterial activity than palladiumcompounds $1-4$. Complexes $1-2$ and 4-5 presented also antioxidant activity with IC50 values in the interval $0.12-0.14 \mu \mathrm{M}$. The nature of the metal center ( $\mathrm{Pt}$ vs. Pd) does not discriminate upon the radical scavenging activity of the assayed cyclometalated complexes.

With regard to plausible target biomolecules for compounds $1-5$, these metalacycles altered the DNA tertiary structure in a similar way as the standard reference cisplatin but at higher concentrations. Thus, retardation of the DNA mobility was observed at $25 \mu \mathrm{M}$ for compound 5 and at $100 \mu \mathrm{M}$ for compounds 1-4. On the other hand, compounds 1-5 did not present a high activity for the inhibition of cathepsin B, being palladacycles 1-4 more active than platinacycle 5 versus the inhibition of cathepsin $B$. Then, there is no correlation between the cytotoxic activity of the studied compounds 1-5 and their inhibitory activity on this cysteine protease. These results suggest that these classes of compounds (cyclopalladated and platinated benzophenone imines), both with good cytotoxic activity, operate via a different pharmacological mechanism in which DNA and cathepsin B are not the primary targets.

Work is in progress in our research group with the aims of firstly finding out a plausible primary target biomolecule for these compounds, then to functionalize compounds $1-5$ in an adequate form in order to increase their potency as anticancer agents, and also to study the mechanism through that these compounds scavenges the DPPH radicals. 
522 Acknowledgements

523

524 We are grateful to the Ministerio de Ciencia y Tecnología (Grant CTQ2009-11501), the AGAUR

525 (Generalitat de Catalunya, Grant 2009-SGR-1111) and Higher Education Commission of Pakistan 526 (Grant No. 20-1434) for the financial support. 


\section{References}

[1] N. Cutillas, G.S. Yellol, C. de Haro, C. Vicente, V. Rodríguez, J. Ruiz, Coord. Chem. Rev. 257 (2013) 2784-2797.

[2] Q. Zhao, C. Huang, F. Li, Chem. Soc. Rev. 40 (2011) 2508-2524.

[3] V. Fernández-Moreira, F.L. Thorp-Greenwood, M.P. Coogan, Chem. Commun. 46 (2010) 186202.

[4] J. Albert, R. Bosque, M. Crespo, J. Granell, C. López, R. Cortés, A. Gonzalez, J. Quirante, C. Calvis, R. Messeguer, L. Baldomà, J. Badia, M. Cascante, Bioorg. Med. Chem. 21 (2013) 42104217.

[5] D. Talancón, C. López, M. Font-Bardia, T. Calvet, J. Quirante, C. Calvis, R. Messeguer, R. Cortés, M. Cascante, L. Baldomà, J. Badia, J. Inorg. Biochem. 118 (2013) 1-12.

[6] R. Cortés, M. Crespo, L. Davin, R.Martín, J. Quirante, D. Ruiz, R.Messeguer, C. Calvis, L. Baldomà, J. Badia, M. Font-Bardia, T. Calvet, M. Cascante, Eur. J. Med. Chem. 54 (2012) $557-$ 566.

[7] J. Quirante,D. Ruiz,A.Gonzalez, C. López,M.Cascante,R. Cortés, R.Messeguer,C. Calvis, L. Baldomà, A. Pascual, Y. Guérardel, B. Pradines, M. Font-Bardia, T. Calvet, C. Biot, J. Inorg. Biochem. 105 (2011) 1720-1728.

[8] A.C.F. Caires, Anti Cancer Agents Med. Chem. 7 (2007) 484-491.

[9] A. Gómez Quiroga, C. Navarro Ranninger, Coord. Chem. Rev. 248 (2004) 119-133.

[10] M. Adams, C. de Kock, P.J. Smith, K. Chibale, G.S. Smith, J. Organomet. Chem. 736 (2013) 19-26.

[11] P. Chellan, K.M. Land, A. Shokar, A. Au, S.H. An, C.M. Clavel, P.J. Dyson, C. de Kock, P.J. Smith, K. Chibale, G.S. Smith, Organometallics 31 (2012) 5791-5799.

[12] S.P. Fricker, R.M. Mosi, B.R. Cameron, I. Baird, Y. Zhu, V. Anastassov, J. Cox, P.S. Doyle, E. Hansell, G. Lau, J. Langille, M. Olsen, L. Qin, R. Skerlj, R.S.Y. Wong, Z. Santucci, J.H. McKerrow, J. Inorg. Biochem. 102 (2008) 1839-1845.

[13] E. Budzisz, R. Bobka, A. Hauss, J.N. Roedel, S. Wirth, I.P. Lorenz, B. Rozalska, M. Więckowska-Szakiel, U. Krajewskad, M. Rozalskid, Dalton Trans. 41 (2012) 5925-5933.

[14] H.J. Lee, S.H. Lee, H.C. Kim, Y.-E. Lee, S. Park, J. Organomet. Chem. 717 (2012) 164-171.

[15] A.C. Moro, A.C. Urbaczek, E.T. De Almeida, F.R. Pavan, C.Q.F. Leite, A.V.G. Netto, A.E. Mauro, J. Coord. Chem. 65 (2012) 1434-1442.

[16] A.C. Moro, A.E. Mauro, A.V.G. Netto, S.R. Ananias, M.B. Quilles, I.Z. Carlos, F.R. Pavan, C.Q.F. Leite, M. Hörner, Eur. J. Med. Chem. 44 (2009) 4611-4615.

[17] M.B. Dinger, W. Henderson, J. Organomet. Chem. 560 (1998) 233-243.

[18] R.V. Parish, J.Mack, L. Hargreaves, J.P.Wright, R.G. Buckley, A.M. Elsome, S.P. Fricker, B.R.C. Theobald, J. Chem. Soc. Dalton Trans. (1996) 69-74.

[19] N.P.E. Barry, P.J. Sadler, Chem. Commun. 49 (2013) 5106-5131.

[20] M.M. Mohamed, B.F. Sloane, Nat. Rev. Cancer 6 (2006) 764-775. 
567

568

569

570

571

572

573

574

575

576

577

578

579

580

581

582

583

584

585

586

587

588

589

590

591

592

593

594

595

596

597

598

599

600

601

602

603

604

[21] S.P. Fricker, Metallomics 2 (2010) 366-377.

[22] J. Spencer, A. Casini, O. Zava, R.P. Rathnam, S.K. Velhanda, M. Pfeffer, S.K. Callear, M.B. Hursthoused, P.J. Dyson, Dalton Trans. (2009) 10731-10735.

[23] J. Spencer, R.P. Rathnam,M. Motukuri, A.K. Kotha, S.C.W. Richardson, A. Hazrati, J.A. Hartley, L. Louise, M.B. Hursthouse, Dalton Trans. (2009) 4299-4303.

[24] S.S. Gunatilleke, A.M. Barrios, J. Inorg. Biochem. 102 (2008) 555-563.

[25] R. Mosi, I.R. Baird, J. Cox, V. Anastassov, B. Cameron, R.T. Skerlj, S.P. Fricker, J. Med. Chem. 49 (2006) 5262-5272.

[26] T.S. Abondanza, C.R. Oliveira, C.M.V. Barbosa, F.E.G. Pereira, R.L.O.R. Cunha, A.C.F. Caires, C. Bincoletto, Food Chem. Toxicol. 46 (2008) 2540-2545.

[27] A.Casini,C. Gabbiani, F. Sorrentino,M.P. Rigobello,A. Bindoli,T.J. Geldbach,A.Marrone, N. Re, C.G. Hartinger, P.J. Dyson, L. Messori, J. Med. Chem. 51 (2008) 6773-6781.

[28] N. Cutillas, A. Martínez, G.S. Yellol, V. Rodríguez, A. Zamora, M. Pedreño, A. Donaire, Ch. Janiak, J. Ruiz, Inorg. Chem. 52 (2013) 13529-13535.

[29] C.Bincoletto, I.L.S. Tersariol, C.R. Oliveira, S. Dreher, D.M. Fausto, M.A. Soufen, F.D. Nascimento, A.C.F. Caires, Bioorg. Med. Chem. 13 (2005) 3047-3055.

[30] S.S. Gunatilleke, A.M. Barrios, J. Med. Chem. 49 (2006) 3933-3937.

[31] R.L.O.R. Cunha,M.E. Urano, J.R. Chagas, P.C. Almeida, C. Bincoletto, I.L.S. Tersariol, J.V. Comasseto, Bioorg. Med. Chem. Lett. 15 (2005) 755-760.

[32] J. Albert, S. García, J. Granell, A. Llorca, M.V. Lovelle, V.Moreno, A. Presa, L. Rodríguez, J. Quirante, C. Calvis, R. Messeguer, J. Badía, L. Baldomà, J. Organomet. Chem. 724 (2013) 289296.

[33] V.Y. Kukushkin, A.J.L. Pombeiro, C.M.P. Ferreira, L.I. Elding, Inorg. Synth. 33 (2002) 189196.

[34] SAINT Bruker, Bruker AXS Inc., Madison, Wisconsin, USA, 2007.

[35] G.M. Sheldrick, Acta Crystallogr. A64 (2008) 112-122.

[36] K.T. Givens, S. Kitada, A.K. Chen, J. Rothschiller, D.A. Lee, Investig. Ophthalmol. Vis. Sci. $31(1990) 1856$.

[37] A. Felten, B. Grandry, P.H. Lagrange, I. Casin, J. Clin. Microbiol. 40 (2002) 2766-2771.

[38] M. Jamil, I.U. Haq, B.Mirza, M.Qayyum, Ann. Clin.Microbiol. Antimicrob. 11 (2012) 11.

[39] S. Arikan, V. Paetznick, J.H. Rex, Antimicrob. Agents Chemother. 46 (2002) 3084-3087.

[40] G. Cao, E. Sofic, R.L. Prior, J. Agric. Food Chem. 44 (1996) 3426-3431.

[41] H. Nawaz, Z. Akhter, S. Yasmeen, H.M. Siddiqi, B. Mirza, A. Rifat, J. Organomet. Chem. 694 (2009) 2198-2203.

[42] A. Abdullah, F. Huq, A. Chowdhury, H. Tayyem, P. Beale, K. Fisher, BMC Chem. Biol. 6 (2006), http://dx.doi.org/10.1186/1472-6769-6-3.

[43] Y.Y. Scaffidi-Domianello, A.A. Nazarov, M. Haukka, M. Galanski, B.K. Keppler, J. Schneider, P. Du, R. Eisenberg, V.Y. Kukushkin, Inorg. Chem. 46 (2007) 4469-4482. 
[44] S.U. Pandya, K.C.Moss,M.R. Bryce, A.S. Batsanov, M.A. Fox, V. Jankus, H.A. Al Attar, A.P. Monkman, Eur. J. Inorg. Chem. (2010) 1963-1972.

[45] J. Albert, R. Bosque, L. D'Andrea, J. Granell, M. Font-Bardia, T. Calvet, Eur. J. Inorg. Chem. (2011) 3617-3631.

[46] J. Albert, L. D'Andrea, J. Granell, R. Tavera, M. Font-Bardia, X. Solans, J. Organomet. Chem. 692 (2007) 3070-3080.

[47] J. Albert, J.M. Cadena, A. González, J. Granell, X. Solans, M. Font-Bardia, Chem. Eur. J. 12 (2006) 887-894.

[48] J. Albert, J. Granell, J. Sales, M. Font-Bardia, X. Solans, Organometallics 14 (1995) 1393-1404.

[49] X. Riera, A. Caubet, C. López, V. Moreno, X. Solans, M. Font-Bardia, Organometallics 19 (2000) 1384-1390.

[50] A. Capapé, M. Crespo, J. Granell, M. Font-Bardia, X. Solans, J. Organomet. Chem. 690 (2005) 4309-4318.

[51] J.L. García-Ruano, I. López-Solera, J.R. Masaguer, M.A. Monge, C. Navarro-Ranninger, J.H. Rodríguez, J. Organomet. Chem. 476 (1994) 111-120.

[52] R. Martín, M. Crespo, M. Font-Bardia, T. Calvet, Polyhedron 28 (2009) 1369-1373.

[53] A.F. Shorr, Crit. Care Med. 37 (2009) 1463-1469.

[54] R. Nath, S. Roy, B. De, M.D. Choudhury, Int. J. Pharm. Pharm. Sci. 5 (Suppl. 2) (2013) 63-69.

[55] R. Wilken, M.S. Veena, M.B. Wang, E.S. Srivatsan, Mol. Cancer 10 (2011) 12.

[56] J.H. Lee, T.O. Khor, L. Shu, Z.Y. Su, F. Fuentes, A.N. Tony Kong, Pharmacol. Ther. 137 (2013) $153-171$.

[57] F. Tosetti, D.M. Noonan, A. Albin, Int. J. Cancer 125 (2009) 1997-2003.

[58] S. Nair, W. Li, A.N. Tony Kong, Acta Pharmacol. Sin. 28 (2007) 459-472.

[59] M.S. Al Moundhri, S. Al-Salam, A. Al Mahrouqee, S. Beegam, B.H. Ali, J. Med. Toxicol. 9 (2013) 25-33.

[60] M.U. Nessa, P. Beale, C. Chan, J.Q. Yu, F. Huq, Anticancer Res. 32 (2012) 4843-4850.

[61] P. Ferroni, D. Della-Morte, R. Palmirotta, M. McClendon, G. Testa, P. Abete, F. Rengo, T. Rundek, F. Guadagni, M. Roselli, Rejuvenation Res. 14 (2011) 293-308.

[62] V.D. Sen, V.D. Sen, A.A. Terent'ev, N.P. Konovalova, Russ. Chem. Bull. 60 (2011) 1342-1352.

[63] S. van Zutphen, M. Kraus, C. Driessen, G.A. van der Marel, H.S. Overkleeft, J. Reedijk, J. Inorg. Biochem. 99 (2005) 1384-1389. 
637

638

639

640

641

642

643

644

645

646

647

648

649

650

651

652

653

654

655

656

657

658

659

660

661

662

663

664

665

666

\section{Legends to figures}

Scheme 1. i) $\mathrm{Pd}(\mathrm{OAc}) 2$ (stoichiometric), $\mathrm{HOAc}, 60^{\circ} \mathrm{C}, 24 \mathrm{~h}$; ii) $\mathrm{LiCl}$ (excess), acetone, r.t., $2 \mathrm{~h}$; iii) $\mathrm{PPh} 3$ (stoichiometric), acetone, r.t., 2 h.; iv) cis-[PtCl2(DMSO)2], NaOAc (stoichiometric), benzophenone imine (excess), methanol, reflux, 24 h, under N2.

Figure 1. Crystal structure of compound 5. Hydrogen atoms have been omitted for clarity. Selected bond distances $(\AA)$ and angles $\left({ }^{\circ}\right)$ : $\mathrm{Pt}(1)-\mathrm{C}(13)=2.0110(12), \operatorname{Pt}(1)-\mathrm{N}(1)=2.0485(10), \operatorname{Pt}(1)-\mathrm{P}(1)=$ 2.2347(4), $\mathrm{Pt}(1)-\mathrm{Cl}(1)=2.3622(4), \mathrm{N}(1)-\mathrm{C}(1)=1.3000(16), \mathrm{C}(1)-\mathrm{C}(8)=1.4586(17), \mathrm{C}(8)-\mathrm{C}(13)=$ 1.4279(17), C(13)-Pt(1)-N(1) = 79.80(5), C(13)-Pt(1)-P(1) = 96.66(4), N(1)-Pt(1)-P(1) = 173.76(3), $\mathrm{C}(13)-\mathrm{Pt}(1)-\mathrm{Cl}(1)=167.74(4), \mathrm{N}(1)-\mathrm{Pt}(1)-\mathrm{Cl}(1)=88.09(3), \mathrm{P}(1)-\mathrm{Pt}(1)-\mathrm{Cl}(1)=95.584(14), \mathrm{C}(8)-$ $\mathrm{C}(13)-\mathrm{Pt}(1)=113.06(8), \mathrm{C}(13)-\mathrm{C}(8)-\mathrm{C}(1)=115.17(11), \mathrm{N}(1)-\mathrm{C}(1)-\mathrm{C}(8)=114.14(10)$.

Figure 2. Interaction of pBluescript $\mathrm{SK}+$ plasmidDNA $(0.8 \mu \mathrm{g})$ with increasing concentrations of compound 5, cisplatin and ethidiumbromide. Lane 1: DNA only. Lane 2: $2.5 \mu \mathrm{M}$. Lane 3: $5 \mu \mathrm{M}$. Lane 4: $10 \mu \mathrm{M}$. Lane 5: $25 \mu \mathrm{M}$. Lane 6: $50 \mu \mathrm{M}$. Lane 7: $100 \mu \mathrm{M}$. Lane 8: $200 \mu \mathrm{M}$. ccc $=$ supercoiled closed circular DNA. oc $=$ open circular DNA.

Figure 3. Structural formula of the compounds under discussion for the cathepsin B inhibition. Compounds X: Dinuclear biphosphane palladacycles [reference 22]. Compounds Y: Mononuclear platinacycles with a fluorinated phosphane [reference 28]. Compounds Z: Mononuclear cyclopalladated and cycloautared compounds [reference 12].

Figure 4. Effect of compounds $1-5$ on cathepsin B activity. The enzyme was preincubated for $24 \mathrm{~h}$ with $10 \mu \mathrm{M}$ (blue bars), $50 \mu \mathrm{M}$ (brown bars) or $100 \mu \mathrm{M}$ (green bars) of each compound. The activity is given as a percentage of the enzyme activity determined in the absence of the test compound. Data are shown as the mean values of the experiment performed in triplicate with the corresponding standard deviation. 
667 Table 1 IC50 $(\mu \mathrm{M})(50 \%$ inhibitory concentration) cytotoxicity for benzophenone imine, compounds $6681-5$ and cisplatin. Data are shown as the mean values of two experiments performed in triplicate with 669 the corresponding standard deviation.

\begin{tabular}{|c|c|c|c|}
\hline \multirow[t]{3}{*}{ Test compound } & \multicolumn{3}{|l|}{$\mathrm{K}_{\infty}(\mu \mathrm{M})$} \\
\hline & \multicolumn{3}{|l|}{ Gances cell line } \\
\hline & MAMB-231 & MOF-7 & HCT-116 \\
\hline Benzophenone imine & $>100$ & $>100$ & $>100$ \\
\hline 1 & $150 \pm 12^{2}$ & $140 \pm 42^{4}$ & $33 \pm 3$ \\
\hline 2 & $13 \pm 1^{2}$ & $11.0 \pm 1.5^{2}$ & $200 \pm 0.7$ \\
\hline 3 & $1.1 \pm 0.3^{5}$ & $40 \pm 05^{2}$ & $18 \pm 2$ \\
\hline 4 & $1.1 \pm 0.1^{2}$ & $41 \pm 09^{2}$ & $20 \pm 5$ \\
\hline 5 & $50 \pm 12$ & $13.4 \pm 1.5$ & $110 \pm 0.6$ \\
\hline Cisplatin" & $6.5 \pm 2.4$ & $190 \pm 45$ & $\infty 00 \pm 44$ \\
\hline
\end{tabular}


673 Table 2 Antibacterial activity of compounds 1-5. S. aureus: Staphylococcus aureus. M. luteus: 674 Micrococcus luteus. B. subtilis: Bacillus subtilis. E. coli: Escherichia coli. E. aerogenes: Enterobacter 675 aerogenes. B. bronchi: Bordetella bronchiseptica. Triplicate plates of each bacterial strain were prepared.

676

\begin{tabular}{|c|c|c|c|c|c|c|}
\hline \multirow[t]{3}{*}{ Test compound $(\mathrm{MW})^{\mathrm{s}}$} & \multicolumn{6}{|c|}{$M C^{-1}\left[\mu g \times m L^{-1}(\mu \mathrm{M})\right]$} \\
\hline & \multicolumn{6}{|l|}{ Bacterial strain } \\
\hline & S. aurase & M lutrus & A subelise & $E$ colf & E. arogenest & B. bronder ${ }^{4}$ \\
\hline $1(69138)$ & $\sim^{\prime}$ & - & - & - & $150 \pm 2(0.22)$ & $150 \pm 1(0.22)$ \\
\hline $2(64420)$ & - & $200 \pm 3(0.31)$ & - & $200 \pm 2(0.31)$ & $150 \pm 2(0.23)$ & - \\
\hline $3(60797)$ & - & - & - & - & $1500 \pm 25(0.25)$ & $1500 \pm 1.5(0.25)$ \\
\hline $4(58438)$ & - & - & $200 \pm 2(0.34)$ & - & $200 \pm 1(0.34)$ & - \\
\hline $5(67304)$ & $125 \pm 1(0.18)$ & $>200$ & $180 \pm 3(0.27)$ & $170 \pm 1(0.25)$ & $160 \pm 1(0.24)$ & $1400 \pm 0.5(0.21)$ \\
\hline ceffxime ( 453.45 ) & $200 \pm 05(004)$ & $20 \pm 1(0.15)$ & $50 \pm 2(0.11)$ & $50 \pm 1(2.11)$ & $800 \pm 0.5(0.18)$ & $60 \pm 1(0.13)$ \\
\hline roxithromydin $(837047)$ & $150 \pm 3(0.18)$ & $700 \pm 3(0.4)$ & $600 \pm 1(a .72)$ & $600 \pm 2(0.72)$ & $500 \pm 2(0.60)$ & $70 \pm 2(008)$ \\
\hline
\end{tabular}

678

679 
680 Table 3 Antioxidant activity of compounds 1-5 expressed as the \% of DPPH free radical scavenging. 681 Each concentration for the test compounds $(200,100,40,20,10$ and $5 \mu \mathrm{g} / \mathrm{mL})$ was assayed in triplicate.

\begin{tabular}{|c|c|c|c|c|c|c|c|}
\hline \multirow[t]{3}{*}{ Testcompound $(\mathrm{MW})^{f}$} & \multicolumn{6}{|c|}{ Iscavenging $\pm S D^{n}$} & \multirow[t]{3}{*}{$\mathrm{K}_{\operatorname{mos}} \mathrm{H} / \mathrm{g} / \mathrm{mL}(\mu \mathrm{M})$} \\
\hline & \multicolumn{6}{|c|}{ Concentration $\mu g / m L$. (test compound) } & \\
\hline & 200 & 100 & 40 & 20 & 10 & 5 & \\
\hline $2(64420)$ & $\theta \pm 2$ & $52 \pm 1$ & $34 \pm 1$ & $220 \pm 0.5$ & $12 \pm 1$ & $5 \pm 1$ & $900 \pm$ as (a.14) \\
\hline $3(60797)$ & $46 \pm 1$ & $370 \pm 0.5$ & $220 \pm 0.5$ & $160 \pm 0.5$ & $30 \pm 0.5$ & 0 & $>200$ \\
\hline $4(58438)$ & $72 \pm 2$ & $56 \pm 2$ & $38 \pm 2$ & $21 \pm 1$ & $14 \pm 1$ & $9 \pm 2$ & $74 \pm 1(0.13)$ \\
\hline $5(67304)$ & $81 \pm 3$ & $57 \pm 0.5$ & $33 \pm 1$ & $240 \pm 0.5$ & $16 \pm 2$ & $1 \pm 1$ & $81 \pm 1(a .12)$ \\
\hline
\end{tabular}

683

684 
685

686

687

688

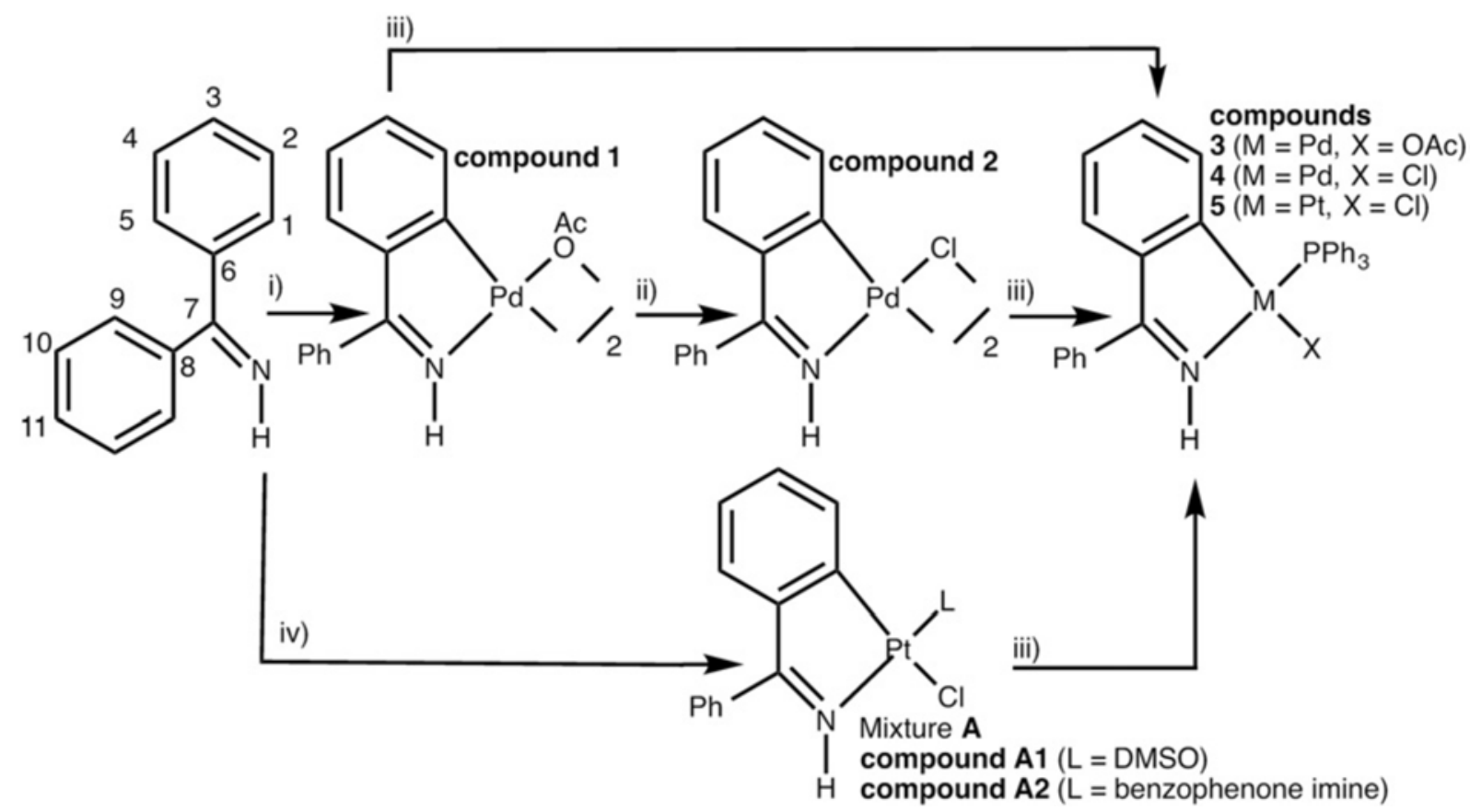

689

Scheme 1

690

691

692 
693

694

695

696

697

698

699

700

701
Figure 1

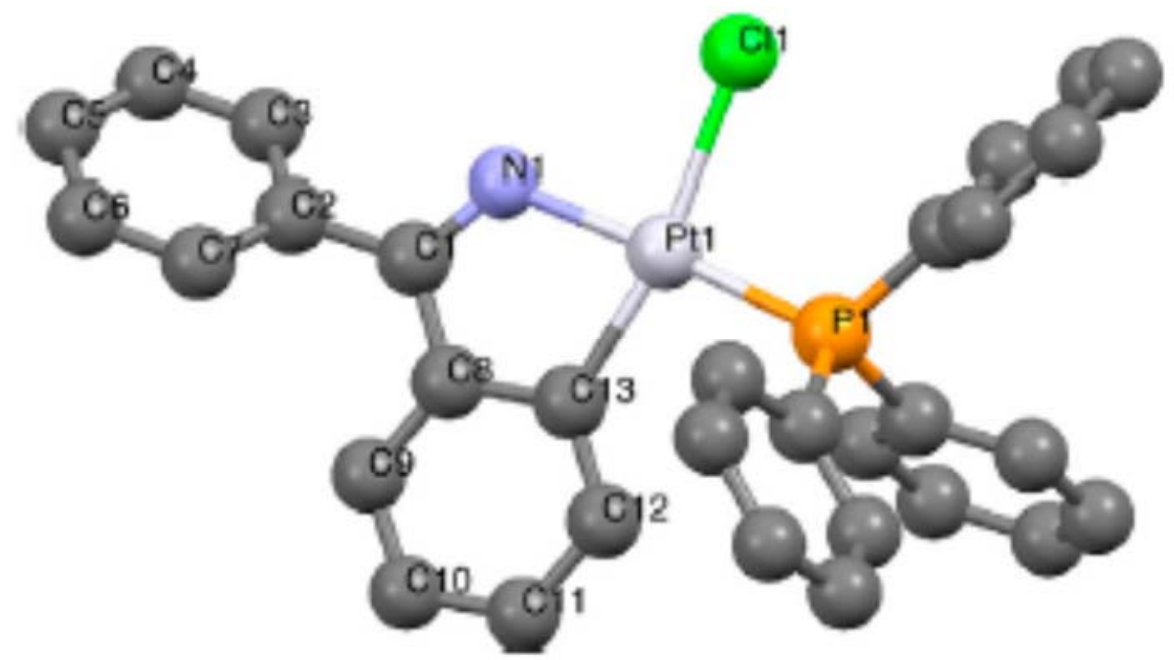


703

704

705

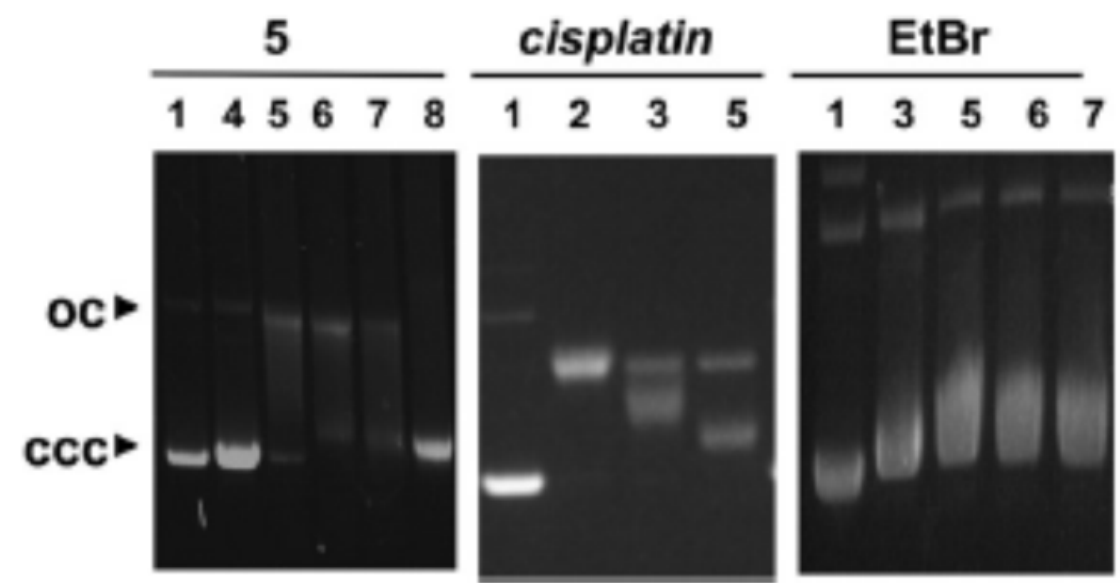

706

707

708

709 
711

712
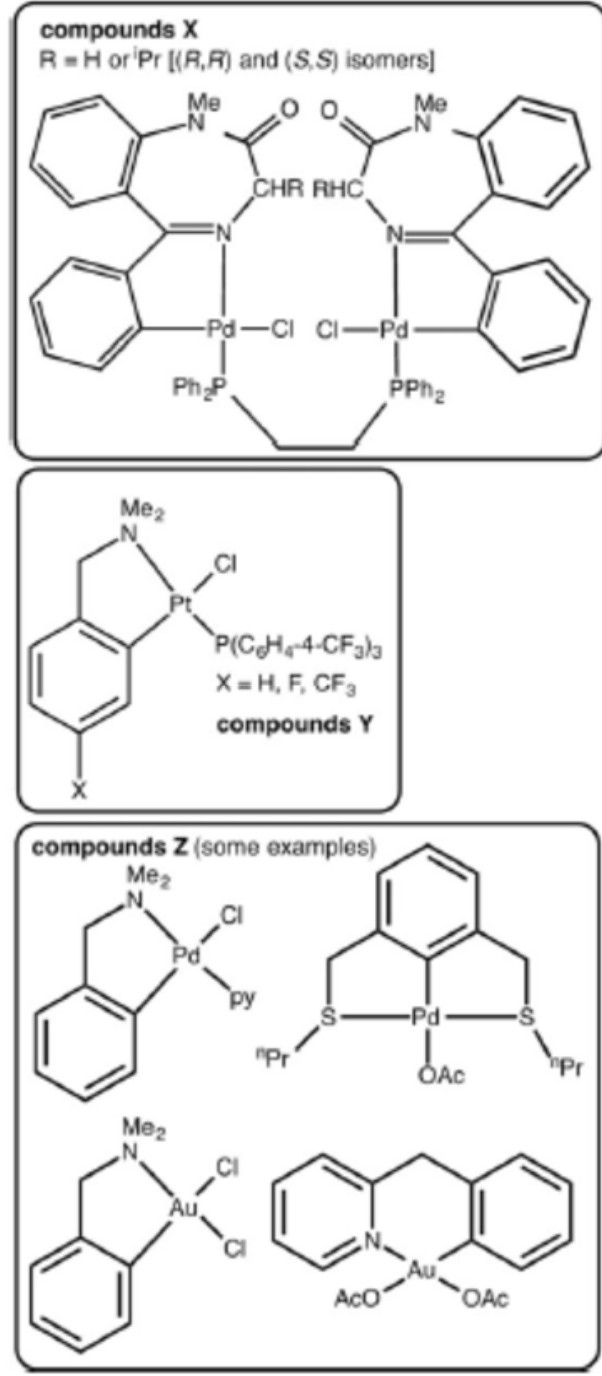
Figure 4

718

719

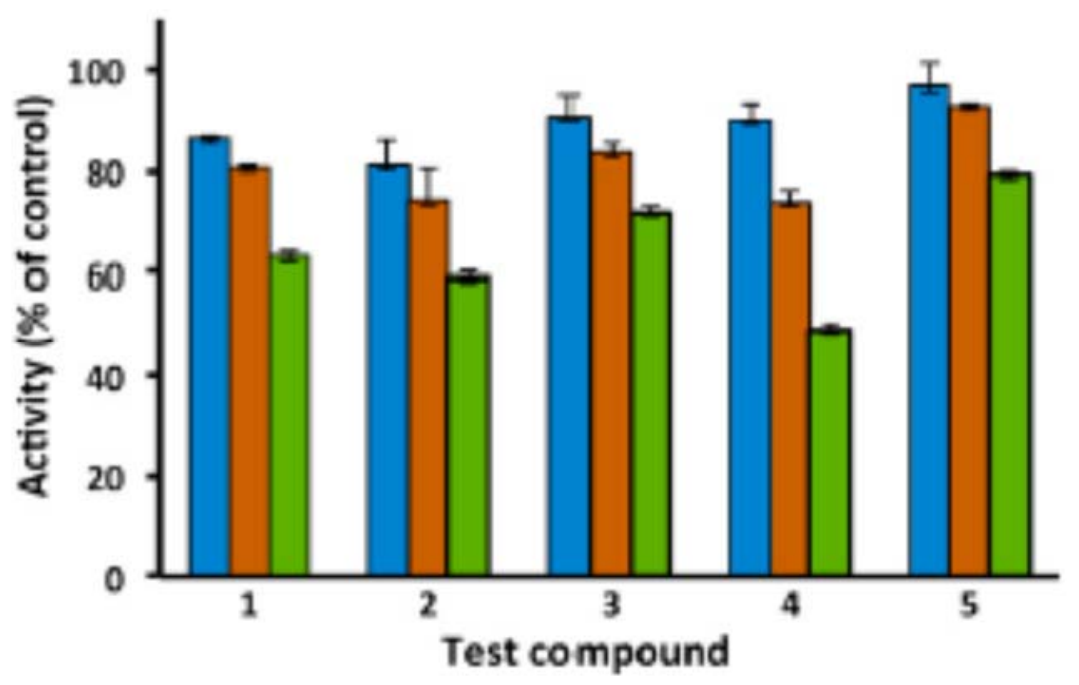

720

721

722

723 